\title{
Implication of Electrostatic Forces on the Adsorption Capacity of a Modified Brick for the Removal of Divalent Cations from Water
}

\author{
Oscar Allahdin1, Michel Wartel2 ${ }^{2}$, Joseph Mabingui1, Abdel Boughriet ${ }^{2,3 *}$ \\ ${ }^{1}$ Chaire Unesco “On the Management of Water", Lavoisier Laboratory of Hydrosciences, Faculty of Sciences, \\ University of Bangui, Bangui, Central African Republic \\ ${ }^{2}$ Laboratory of Geosystems, and Analytical and Marine Chemistry, University of Lille, UMR CNRS 8217, BâtC8, \\ 59655 Villeneuve d'Ascq cedex, France \\ ${ }^{3}$ Department of Chemistry, I.U.T of Béthune, University of Lille, Northern France, Rue de l'Université, B.P.819, \\ 62408 Béthune Cedex, France \\ Email: ${ }^{*}$ abdel.boughriet@univ-lille1.fr
}

Received 5 October 2014; revised 22 November 2014; accepted 9 December 2014

Copyright (C) 2015 by authors and Scientific Research Publishing Inc.

This work is licensed under the Creative Commons Attribution International License (CC BY).

http://creativecommons.org/licenses/by/4.0/

(c) (i) Open Access

\begin{abstract}
Adsorption properties of brick for the removal of divalent cations increased significantly after this material were pre-activated by $\mathrm{HCl}$ and subsequently impregnated with ferrihydrite. Scanning electron microscopy (SEM) and energy dispersive X-ray spectroscopy (EDS) analysis demonstrated that ferrihydrite was preferentially attached to clays (mainly to metakaolinite) and possessed $\mathrm{Na}$ atoms at levels higher than those observed in iron-poor aggregates. Sodium is bound to hydroxyl groups which have a function as reactive sites and give rise to surface charge. Zeta potential measurements were conducted to determine the isoelectric point (IEP) and salt-addition method was used to assess the point of zero charge (PZC) of this brick. Modified brick has a positive charge in water up to $\mathrm{pH} \approx 3.2$ and negative charge above this $\mathrm{pH}$. Moreover, $\mathrm{pH}$ was found to be the most important factor affecting the adsorption process, suggesting the possible implication of electrostatic forces at the brick-water interface. The complexation model proposed by James and Healy was applied to our system: theoretical data on free-energy changes due to effects associated both with electrostatic attraction and solvation, were found to be in agreement with those determined from kinetic experiments. Column experiments permitted further to show that adsorption reactions were strongly inhibited by addition of an inert electrolyte (like $\mathrm{NaNO}_{3}$ ). Under this condition, ionic strength increased and most surface sites of the brick would be occupied by $\mathrm{Na}^{+}$ions, leading
\end{abstract}

"Corresponding author.

How to cite this paper: Allahdin, O., Wartel, M., Mabingui, J. and Boughriet, A. (2015) Implication of Electrostatic Forces on the Adsorption Capacity of a Modified Brick for the Removal of Divalent Cations from Water. American Journal of Analytical Chemistry, 6, 11-25. http://dx.doi.org/10.4236/ajac.2015.61002 
to a charge neutralization and thereby a depletion of electrostatic forces.

Keywords

Brick, Divalent Cation, Adsorption, Electrostatic Forces, Free Energy, Coulombic, Solvation

\section{Introduction}

Adsorption techniques are well-known to be effective methods for water depollution applications [1]-[4]. However, adsorbents which are commonly used in industries (like activated carbon), remain expensive materials to be employed in developing countries. To address this problem, attention has recently been more focused on the applicability of natural and low cost materials that can be locally available by poor people in rural regions.

On this view, works have been undertaken by our research group (which is located both at Lille1 University in France and Bangui University in Central African Republic) to enhance the potential of using brick made by African craftsmen (in Bangui region) as a cheap and non-pollutant adsorbent [5]-[9]. These studies were addressed in terms of first cost effectiveness, and second removal performance and adsorption capacity in the treatments either of riverine waters or ground-waters contaminated by heavy metal cations. From our previous investigations, it was shown that the adsorption process was significantly improved when brick was preliminary activated by $\mathrm{HCl} 6 \mathrm{M}$ at $90^{\circ} \mathrm{C}$ and afterwards impregnated with ferrihydrite. Mechanistic aspects were also examined in these works by showing how metal sequestration occurred in the medium. It revealed the possible implication of electrostatic forces in the binding process which led with time to ion-exchange reactions to form inner sphere, bidendate complexes [9].

Brick is a heterogeneous mixture of fine-grained solids, mainly composed of quartz and clays. To better understand the adsorption behavior of this mineral after activation and its binding mechanisms in aqueous solutions, the present study investigated the chemical nature of the modified-brick surface by exploring it in the micro-scale by means of a scanning electron microscope equipped with an energy dispersive X-ray spectrometer (SEM/EDS). To characterize surface electrochemical properties of brick as its tendency to ionize, electro-kinetic measurements (zeta potential) were made on brick samples. The salt-addition method was applied as well in order to describe the net uptake or release of protons at the water-solid interface, $\Delta \mathrm{pH}$, or surface charge, $\sigma$, which was induced by an increase of ionic strength (by addition of an inert electrolyte: $\mathrm{NaNO}_{3}$ ). On the other hand, the distribution coefficient of the cationic solute between the brick and water was assessed at different temperatures, $20^{\circ} \mathrm{C}-35^{\circ} \mathrm{C}$, and thermodynamic parameters $\left(\Delta G^{0}, \Delta H^{0}\right.$ and $\left.\Delta S^{0}\right)$ relative to the heterogeneous equilibrium were evaluated. To understand energetically this heterogeneous kinetics process, the surface complexation model proposed by James and Healy [10] was used to our system. Theoretical free-energy changes—which derive from the attractive Coulombic forces and repulsive secondary solvation forces at the brick-water interface-were calculated and compared to experimental data.

\section{Materials and Methods}

\subsection{Adsorbent Preparation}

The raw brick used in this study was obtained from Bangui region in the Central African Republic. Previously, $\mathrm{X}$-ray diffraction and chemical analysis were performed on this material: $\sim 61 \mathrm{wt} \%$ quartz; $\sim 21 \mathrm{wt} \%$ metakaolinite; 3 - $4 \mathrm{wt} \%$ illite; $\leq 4 \mathrm{wt} \%$ iron oxides/hydroxides; and $\leq 2 \mathrm{wt} \%$ feldspar + mica + biotite [5]. Before use, several physical/chemical treatments were carried out on the raw brick [5] [6]. Briefly: 1) it was broken into grains and sieved with sizes ranging from 0.7 to $1.0 \mathrm{~mm}$; 2) the resulting particles were leached with a $6 \mathrm{M} \mathrm{HCl}$ solution at $90^{\circ} \mathrm{C}$ for 3 hours; and 3) finally a deposition of $\mathrm{FeOOH}$ onto $\mathrm{HCl}$-treated brick was performed by precipitation of iron(III) with a $\mathrm{NaOH}$ solution up to reach $\mathrm{pH}$ 7. Previously, it was noticed that $\mathrm{HCl}$ concentration, reaction temperature and time had a significant influence on the final meso-structure of the material [6]. Thus, following the acid leaching procedure described above, the surface area (S.A.) was found to increase notably from S.A. $=31.2 \mathrm{~m}^{2} \cdot \mathrm{g}^{-1}$ in the raw brick to S.A. $=70 \mathrm{~m}^{2} \cdot \mathrm{g}^{-1}$ in the modified material. 


\subsection{Chemicals}

All chemicals used in the study were analytical grades. Sodium hydroxide and hydrochloride acid were supplied by DISLAB (France). The following salts: $\mathrm{NaNO}_{3}, \mathrm{Cd}\left(\mathrm{NO}_{3}\right)_{2} \cdot 4 \mathrm{H}_{2} \mathrm{O}, \mathrm{Pb}\left(\mathrm{NO}_{3}\right)_{2}$, and $\mathrm{Sr}\left(\mathrm{NO}_{3}\right)_{2}$ were purchased from Prolabo. $\mathrm{Cu}\left(\mathrm{NO}_{3}\right)_{2} \cdot 3 \mathrm{H}_{2} \mathrm{O}$ was obtained from Scharlau, and $\mathrm{Zn}\left(\mathrm{NO}_{3}\right)_{2} \cdot 6 \mathrm{H}_{2} \mathrm{O}$ from Fluka.

\subsection{Surface Electrochemical Studies}

To evaluate the zeta potential of brick samples, electrophoretic mobility measurements were conducted at $298^{\circ} \mathrm{K}$ using a Zetameter model Zetasizer Nano ZS90 (Malvern Instruments) equipped with a laser He-Ne at $633 \mathrm{~nm}$ (4 $\mathrm{mW}$ maxi.). The electrophoresis cell (folded capillary cell) contains electrodes which are made of solid palladium and can be cleaned physically (by using an ultrasonic bath of clean water, 30 Watts) and chemically. This Zetameter apparatus determines the electrophoretic mobility of the particles automatically and converts it to the zeta ( $\xi$ ) potential by means of Smoluchowski's formula. To prevent cross-contamination, the electrophoresis cell was carefully washed with Milli-Q water several times before zeta analysis. Suspensions were prepared in a nalgene tube by mixing $500 \mathrm{mg}$ of fine-grained brick $(\leq 63 \mu \mathrm{m})$ with $100 \mathrm{~mL}$ Mill-Q water. The $\mathrm{pH}$ was adjusted in the range from 3.0 to 9 before each measurement by drop-wise addition of a diluted solution of either $\mathrm{NaOH}$ $\left(10^{-2} \mathrm{M}\right)$ or $\mathrm{HCl}\left(10^{-2} \mathrm{M}\right)$. The $\mathrm{pH}$ which was measured after zeta-potential analysis was recorded as the final $\mathrm{pH}$.

As described previously [11], salt-addition method was used in this work in order to assess whether modified brick has either a negative or positive surface charge in an aqueous medium. Briefly, $1 \mathrm{~g}$ of this brick was placed in each of 10 " $80-\mathrm{mL}$ " beakers containing $19.5 \mathrm{~mL}$ of Mill-Q water. The $\mathrm{pH}$ of the suspensions was adjusted with $\mathrm{HCl}\left(10^{-2} \mathrm{M}\right)$ or $\mathrm{NaOH}\left(10^{-2} \mathrm{M}\right)$ to span the expected $\mathrm{pH}_{\mathrm{PZC}}$ value. A $0.5 \mathrm{~mL}$ volume of a $0.1 \mathrm{M} \mathrm{NaNO}_{3}$ solution (as an inert electrolyte) was added to these suspensions. All these mixtures were equilibrated for 1 night, by shaking gently at a constant speed of $120 \mathrm{rpm}$ using a mechanical shaker (Model: IKA Labortechnik KS 250 basic). The equilibrium $\mathrm{pH}$ was recorded and designated $\mathrm{pH}_{0.0025 \mathrm{M}}\left(0.0025 \mathrm{M}\right.$ is the final $\mathrm{NaNO}_{3}$ concentration in the medium). Afterwards, a $0.5 \mathrm{~mL}$ volume of a $2 \mathrm{M} \mathrm{NaNO}_{3}$ solution was added to the previous mixtures, and shaken for a few minutes. The $\mathrm{pH}$ was recorded and designated $\mathrm{pH}_{0.052}\left(0.052 \mathrm{M}\right.$ is the final $\mathrm{NaNO}_{3}$ concentration in the resulting suspension). For each beaker, $\Delta \mathrm{pH}=\mathrm{pH}_{0.0525}-\mathrm{pH}_{0.0025 \mathrm{M}}$ was calculated, and $\Delta \mathrm{pH}$ values were plotted against $\mathrm{pH}_{0.0025 \mathrm{M}}$ in order to evaluate the point where $\Delta \mathrm{pH}=0$ is the point of zero charge, PZC.

\subsection{Electron Microscopy Analysis}

Micrographies of representative specimens of modified brick were recorded by using an environmental scanning electron microscope (ESEM, Quanta $200 \mathrm{FEI}$ ). Elemental analysis was performed using ESEM/EDS (ESEM, model: QUANTA-200-FEI, equipped with an Energy Dispersive X-Ray Spectrometer EDS X flash 3001 and monitored by QUANTA-400 software elaborated by Bruker). EDS measurements were carried out at $20 \mathrm{kV}$ at low vacuum (1.00 Torr) and the maximum pulse throughput was $20 \mathrm{kcps}$. Different surface areas ranging from 0.5 to $3.5 \mathrm{~mm}^{2}$ were targeted on brick grains and examined by ESEM/EDS. Micro-observations along different across-sections of brick samples were also performed by ESEM/EDS. Atomic quantifications and mathematical treatments were undertaken using QUANTA-400 software in order to determine the averaged elemental composition of the surface brick and to detect chemical/elemental variabilities.

\subsection{Fixed-Bed Column Experiments}

Continuous flow adsorption experiments were conducted in a fixed-bed glass column with an inner diameter of $12.5 \mathrm{~mm}$, a height of $25 \mathrm{~cm}$, and a medium porosity sintered-pyrex disk at its bottom in order to prevent any loss of material. A bed depth of $8.5 \mathrm{~cm}(10.0-10.5 \mathrm{~g})$ was investigated at a constant flow rate of $10 \mathrm{~mL} / \mathrm{min}$. Before being used in the experiments, about five bed volumes of Milli-Q water were passed through the column for three reasons: 1) to remove any unbound and thin particles/iron oxides/hydroxides; 2) to check the absence of soluble iron at the outlet; and 3) to confirm the stability of the FeOOH coating on brick pellets. The initial concentration of cadmium(II) in the influent was $1.79 \times 10^{-4}$ mole per liter. This content was chosen in this work because it generally represents a maximum level of soluble iron $(\approx 10 \mathrm{mg} / \mathrm{L})$ found in ground waters from the Bangui region. The Cd(II) solution was pumped through the column at a desired flow rate by means of a peristaltic pump (Modern Labo France Type KD1170) in a down-flow mode. During this column experiment, pH 
was measured continuously at room temperature, and effluent samples exiting the bottom of the column were collected at different time intervals and analyzed for metal contents using ICP-AES (Inductively Coupled Plasma-Atomic Emission Spectroscopy; model Varian Pro Axial View). Flow to the column continued until the effluent $\mathrm{Cd}(\mathrm{II})$ concentration at time $t\left(C_{t}\right)$ reached the influent metal concentration $\left(C_{0}\right): C_{t} / C_{0} \approx 0.98$. Performance of the packed bed is described in the present work using the concept of the breakthrough curve.

\section{Results}

\subsection{SEM/EDS Analysis of Modified Brick}

In energy spectra for uncoated brick (i.e., HCl-activated brick), it was observed high levels of silicon, aluminum and oxygen as these are the main elements of raw brick (not shown here). Other elements including $\mathrm{Fe}, \mathrm{Ti}, \mathrm{K}$ and Mg were also observed at lower amounts. Roughly, the detected Si comes both from quartz and clays, and Al mainly from metakaolinite [6].

In energy spectra for coated brick (i.e., brick activated by $\mathrm{HCl}$ and impregnated with ferrihydrite), it was clearly observed iron signals with higher intensities, which confirmed the deposition of iron oxyhydroxide into the surface of brick (Figure 1). Moreover, the energy spectrum of a Fe-rich aggregate (like that targeted and shown in the SEM image of Figure 2) revealed in all cases the presence of an Al signal at a relatively high intensity (Figure 1). This suggested that $\mathrm{FeOOH}$ was attached to alumino-silicates (mainly metakaolinite). To give a better insight into the way iron oxyhydroxide is attached to the brick surface, a detailed micro-observation within an across-section of a modified brick sample was further performed (see Figure 2). The line scannings for $\mathrm{Si}, \mathrm{Al}, \mathrm{Fe}$, and Na did show the non-uniformity of element distributions along the targeted zone: indeed, an increasing level of Fe was observed alongside the iron-oxyhydroxide aggregate (see Figure 2) whereas the level of $\mathrm{Al}$ decreased in this area, proving the attachment of iron preferentially to clay surfaces. In other words, FeOOH deposits-being attached to clays—contributed to "mask", at least partially, alumino-silicates specimens and thereby to deplete the EDS intensity of the $\mathrm{Al}_{\text {(embedded) }}$ peak. In contrast, the line scanning for sodium increased significantly alongside iron oxyhydroxide grains (Figure 2), suggesting that Na atoms are strongly involved in this phase (noted $\equiv \mathrm{SO}^{-} \mathrm{Na}^{+}$). It should however be noted that $\mathrm{Na}$ atoms were detected as well in areas outside Fe-rich aggregates, raising the possibility of their binding with other hydroxyl groups (like silanol and/or aluminol from brick) in addition to -OH functions from iron oxyhydroxides. These bindings were assumed to form during the chemical treatment of brick (i.e., during $\mathrm{Fe}^{3+}$-ions precipitation by adding $\mathrm{NaOH}$ up to $\mathrm{pH}$ 7, leading to ferrihydrite deposition).

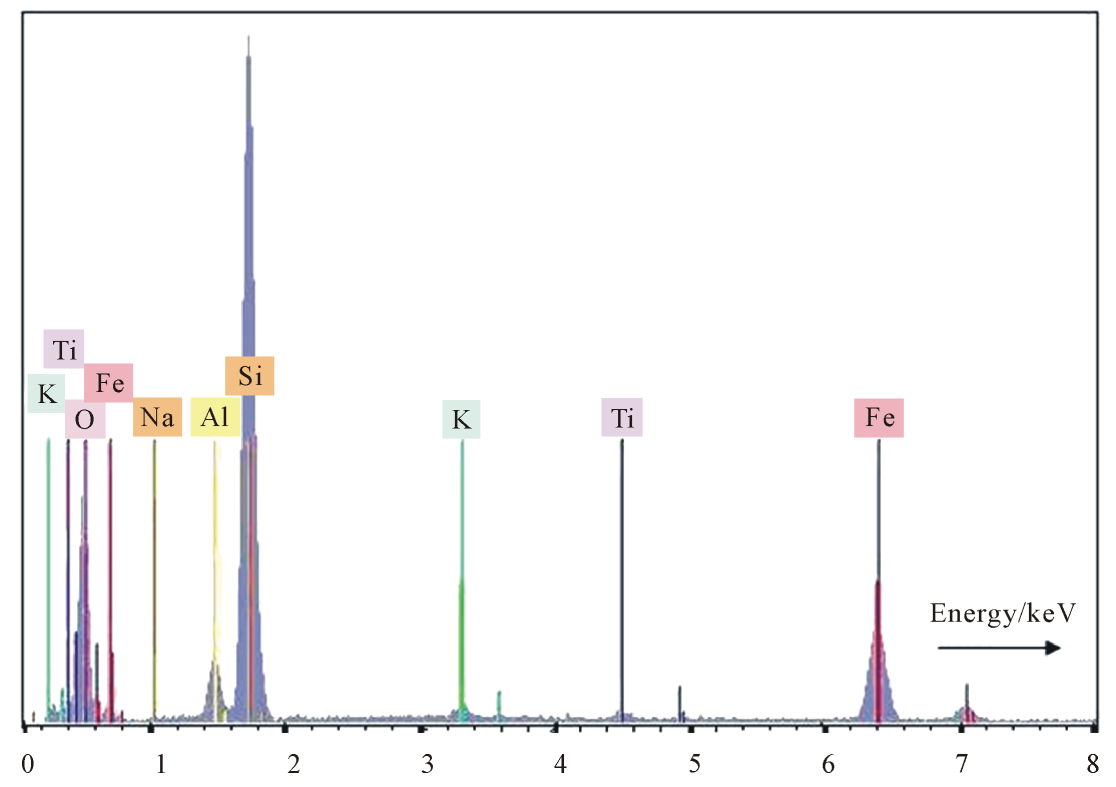

Figure 1. EDS spectrum of an iron-rich particle targeted on the surface of ferrihydrite-coated brick and shown in Figure 2. 

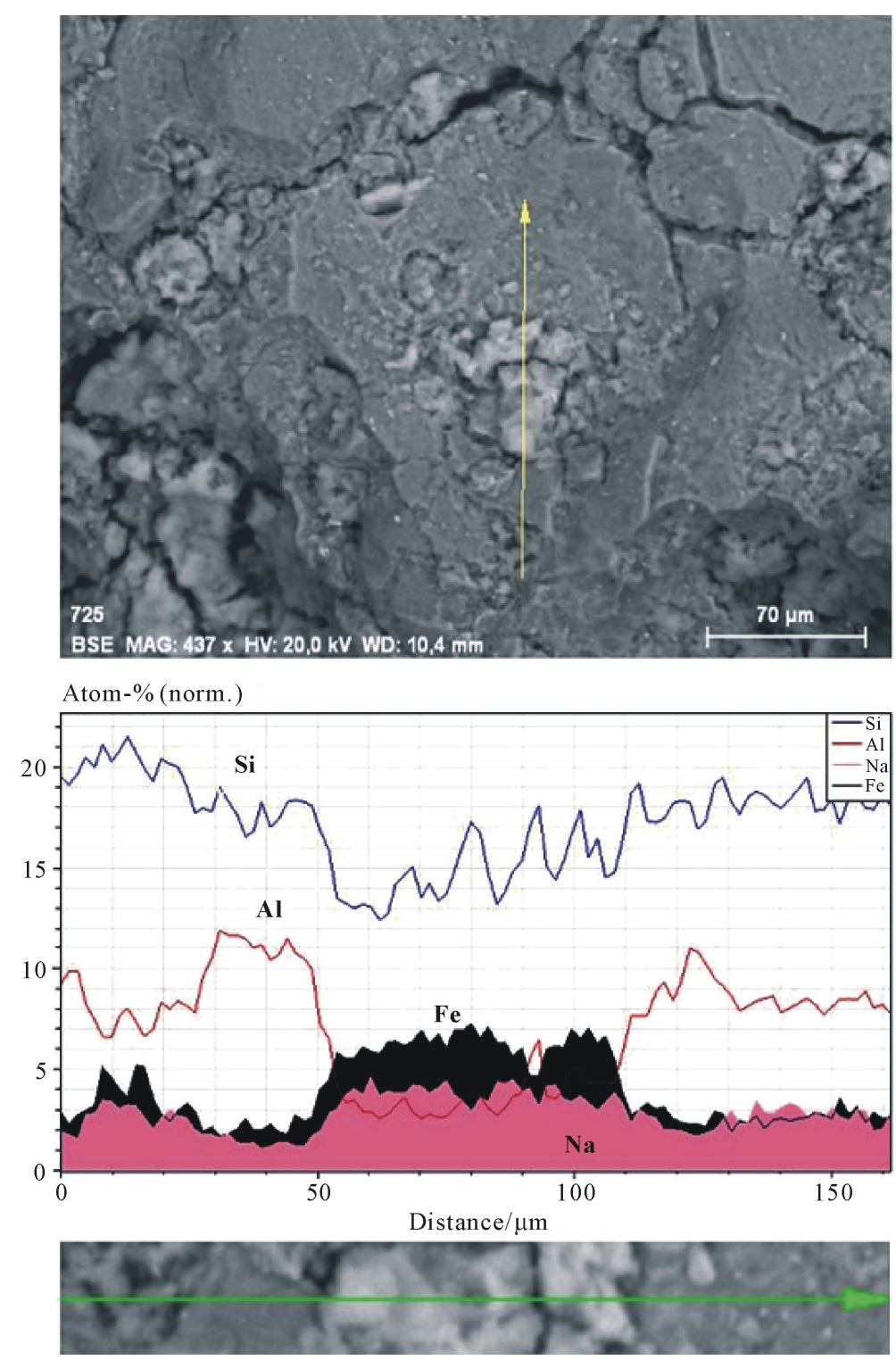

Figure 2. SEM micrograph of ferrihydrite-coated (pre-activated) brick. And EDS analysis of this modified brick within an across-section of this sample, showing the line scannings for $\mathrm{Si}, \mathrm{Al}, \mathrm{Fe}$, and $\mathrm{Na}$.

\subsection{Adsorption Kinetics Thermodynamics}

From previous kinetics studies [7] [12], we examined the evolution of divalent-cation concentration in water in interaction with the adsorbent "brick" and determined the quantity of cation adsorbed onto the brick surface with time (as obtained for $\mathrm{Pb}(\mathrm{II})$ adsorption and shown in Figure 3(a)). When the equilibrium state of this kinetic reaction was attained, the dicationic metal $\left(\mathrm{Me}^{2+}\right)$ adsorbed on brick was in equilibrium with a residual $\mathrm{Me}^{2+}$ content in the liquid phase. The $K_{D}$ ratio was defined as the distribution coefficient of the solute between the adsorbent and the solution in equilibrium:

$$
K_{D}=\frac{C_{\text {ads }}}{C_{\text {eq }}}
$$

where $C_{\text {ads }}$ represents the amount of metal adsorbed on brick at equilibrium; and $C_{e q}$ is the concentration of metal in water at equilibrium [13]-[17]. The enthalpy, $\Delta H^{0}$, and entropy, $\Delta S^{0}$, of the adsorption could be estimated 


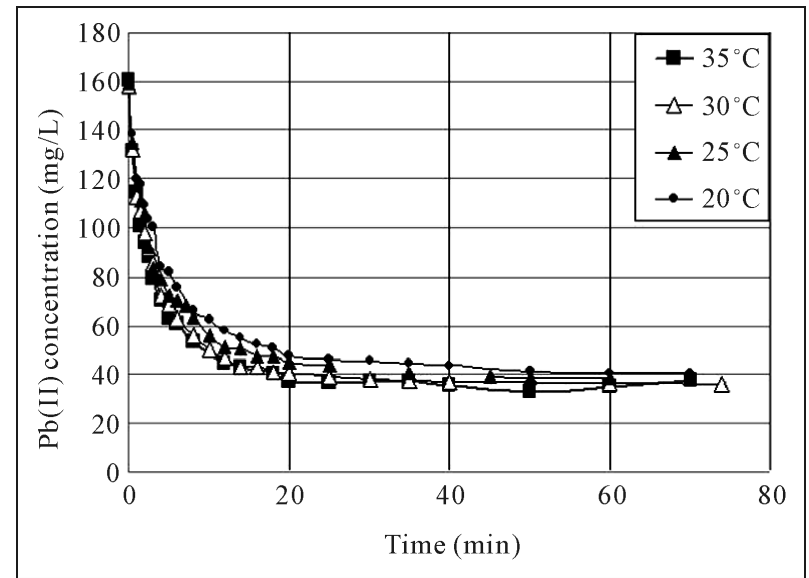

(a)

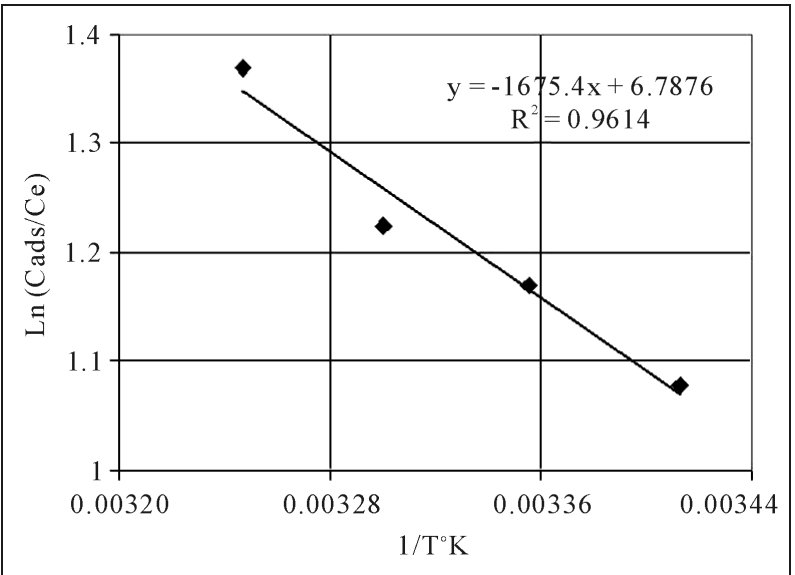

(b)

Figure 3. (a) Variation with time of the amount of lead(II) adsorbed onto modified-brick grains (with 0.7 - $1.0 \mathrm{~mm}$ sizes) at different temperatures ranging from $20^{\circ} \mathrm{C}$ to $35^{\circ} \mathrm{C}$; (b) $\operatorname{Ln}\left(K_{D}\right)$ or $\operatorname{Ln}\left(\right.$ Cads./Ce) plotted against $1 / \mathrm{T}\left({ }^{\circ} \mathrm{K}\right)$, where $K_{D}$ represents the distribution coefficient of lead(II) between brick and water at the equilibrium state.

from Van’t Hoff equation:

$$
\operatorname{Ln} K_{D}=-\frac{\Delta H^{0}}{R T}+\frac{\Delta S^{0}}{R}
$$

For each studied metal, $\operatorname{Ln} K_{D}$ or $\operatorname{Ln}\left(C_{\mathrm{ads}} / C_{\mathrm{eq}}\right)$ was drawn against $1 / T$, and the plot was found to be a straight line with a regression coefficient $R^{2}>0.90$ (as observed for $\mathrm{Pb}(\mathrm{II})$ adsorption and shown in Figure 3(b)). From the slopes and intercepts of the linearized curves, enthalpies $\left(\Delta H^{0}\right)$ and entropies $\left(\Delta S^{0}\right)$ of the different reactions between divalent metals $\left(\mathrm{Cd}^{2+}, \mathrm{Cu}^{2+}, \mathrm{Pb}^{2+}, \mathrm{Sr}^{2+}\right.$, and $\left.\mathrm{Zn}^{2+}\right)$ and brick in water, were evaluated and reported in Table 1. As for Gibbs free energy, $\Delta G^{0}$, it was calculated at $298^{\circ} \mathrm{K}$ from the following equation:

$$
\Delta G^{0}=\Delta H^{0}-T \Delta S^{0}
$$

It is worth noting that the change in free energy for physisorption is between -20 and $0 \mathrm{~kJ} / \mathrm{mole}$, while chemisorption is in the range -80 to $-400 \mathrm{~kJ} / \mathrm{mole}$ [13] [18]. In our case, the Gibbs free energy, $\Delta G^{0}$, for the studied process was found to be in the range of $(-1.4$ to -5.31$) \mathrm{kJ} /$ mole (see Table 1 ), and consequently, the mechanism was predominantly physical adsorption. Energetic data also confirmed the feasibility of the process and the thermodynamically favorable nature of the reaction. Furthermore, the negative values of $\Delta G^{0}$ were much higher 
Table 1. Thermodynamic parameters obtained for the adsorption removal of divalent metals $\left(\mathrm{Cd}^{2+}, \mathrm{Cu}^{2+}, \mathrm{Pb}^{2+}, \mathrm{Sr}^{2+}\right.$, and $\left.\mathrm{Zn}^{2+}\right)$ by modified-brick grains (with $0.7-1.0 \mu \mathrm{m}$ sizes) from water at $298^{\circ} \mathrm{K}$.

\begin{tabular}{cccc}
\hline Metals & $\Delta H^{0}(\mathrm{~kJ} / \mathrm{mole})$ & $\Delta S^{0}(\mathrm{~J} /(\mathrm{mol} \cdot \mathrm{K})$ & $\Delta G^{0} 298 \mathrm{~K}(\mathrm{~kJ} / \mathrm{mole})$ \\
\hline $\mathrm{Cd}^{2+}$ & - & - & -5.940 \\
$\mathrm{Cu}^{2+}$ & +8.838 & +34.16 & -1.342 \\
$\mathrm{~Pb}^{2+}$ & +13.929 & +56.43 & -2.887 \\
$\mathrm{Sr}^{2+}$ & +46.553 & +178.28 & -6.574 \\
$\mathrm{Zn}^{2+}$ & +17.295 & +62.81 & -1.422 \\
\hline
\end{tabular}

than those found for system implicating charge transfer or sharing from adsorbent to adsorbate to form coordinate bonds with $\Delta G^{0} \leq-40 \mathrm{~kJ} / \mathrm{mole}$. The $\Delta G^{0}$ values obtained in this work then agreed better with a physicaladsorption mechanism in which electrostatic interactions between dicationic metals and active brick sites were able to be implicated. It was also noticed that this change of free energy decreased with increase of temperature, indicating clearly that, with increasing temperature the adsorbed amount of divalent metals increased at equilibrium.

Moreover, the positive values of enthalpy change revealed that the adsorption process was endothermic. The magnitude of $\Delta H^{0}$ may also give an idea about the type of sorption involved in our system. Indeed, chemisorption bond strengths are generally in the range of $(+84)-(+420) \mathrm{kJ} / \mathrm{mole}$, while physisorption bond strengths are $<+84 \mathrm{~kJ} / \mathrm{mole}$ [19] [20]. From Table 1, the weak $\Delta H^{0}$ values are in the range of $(+13.9)-(+52.9) \mathrm{kJ} / \mathrm{mole}$, and therefore confirm that $\mathrm{Me}^{2+}$ adsorption by this modified brick occurs more according to a physisorption process rather than a pure chemical adsorption mechanism. As for the highly positive values of $\Delta S^{0}$ (see Table 1), they were consistent with an increase in the degrees of freedom of the implicated species at the solid-liquid interface as a result of structural modifications. These latter were assumed to occur especially when water molecules were released from hydrated metal ions and/or adsorbent surface during the migration of the adsorbate from water to brick. Such structural changes led with time to the generation of solid solutions: $\left(\mathrm{Me}^{2+}\right)_{\mathrm{x}}\left(\mathrm{Fe}^{3+}\right)_{\mathrm{y}} \mathrm{OOH}$, as suggested recently for iron(II) bound to modified brick [8].

To summarize, both the values of $\Delta G^{0}$ and $\Delta H^{0}$ suggested that the adsorption of metallic cations onto brick was a physisorption process.

\subsection{Electro-Kinetic Behavior of Modified Brick in Water}

The $\mathrm{pH}$ of the brick-water system determines the surface charge of the solid particles and thereby should have a relevant control over the uptake of metals. Figure 4(a) illustrates the effect of $\mathrm{pH}$ on the zeta potential of ferrihydrite-coated (pre-activated) brick. It was observed that the positive zeta potential decreased with increasing $\mathrm{pH}$ and its sign reversed at $\mathrm{pH}$ 3.2, which was identified as the isoelectric point (IEP). This indicated that at $\mathrm{pH}>$ $\mathrm{pH}_{\mathrm{IEP}}$ the brick surface possessed negative charges in water and particularly around neutral $\mathrm{pH}$. It is worth noting that the $\mathrm{pH}_{\text {IEP }}$ value obtained for modified brick is higher than that for $\mathrm{HCl}$-activated brick $\left(\mathrm{pH}_{\text {IEP }}=2.2\right)$ and lower than that for raw brick $\left(\mathrm{pH}_{\mathrm{IEP}}=4.0-4.3\right)$, however, it is found to be much lower than that for pure ferrihydrite (IEP = 7.8 [21] [22]), see Figure 4(a).

On the other hand, the $\mathrm{pH}$ at which the net charge on the surface (noted PZC) was zero, was determined in this work by applying the salt-addition method, as described previously [11]. As shown in Figure 4(b), $\Delta \mathrm{pH}=$ $\mathrm{pH}_{0.0525}-\mathrm{pH}_{0.0025}$ was plotted against $\mathrm{pH}_{0.0025 \mathrm{M}}$ (for more details, see the experimental section 2.3), and the resulting curve permitted to attain the $\mathrm{pH}_{\mathrm{PZC}}$ of this material: $\mathrm{pH} \sim 3.0$ - 3.3. It can be noticed that this $\mathrm{pH}_{\mathrm{PZC}}$ value is close to $\mathrm{pH}_{\mathrm{IEP}}$. Cation adsorption takes place favorably when the $\mathrm{pH}_{\mathrm{PZC}}$ of oxides is below the solution $\mathrm{pH}$. In our experimental applications performed in the field, the $\mathrm{pH}$ of treated waters and/or wastewaters were generally found to be higher than 4 and hence made modified-brick surfaces negatively charged and active for cations removal. This implied that electrostatic attractions between metallic cations and brick surfaces should intervene. In this hypothesis, in what follows we had tried to appraise the importance of electrostatic forces in this adsorption process. 


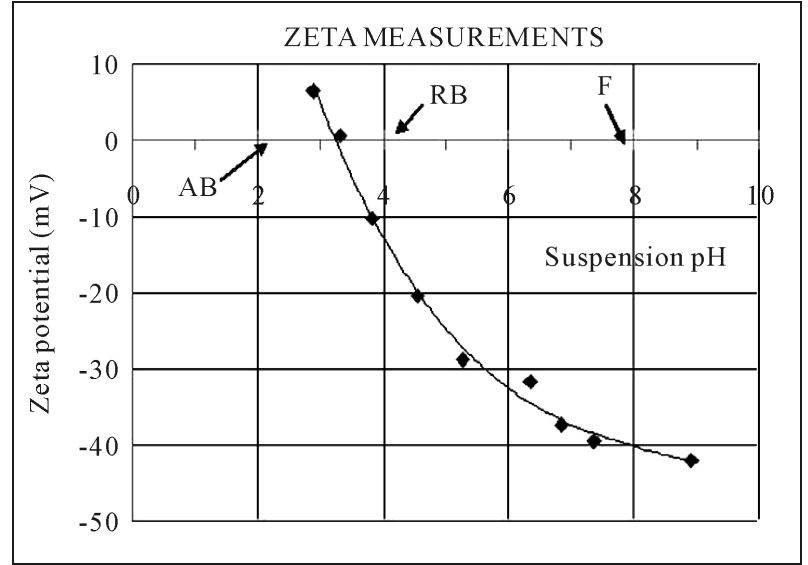

(a)

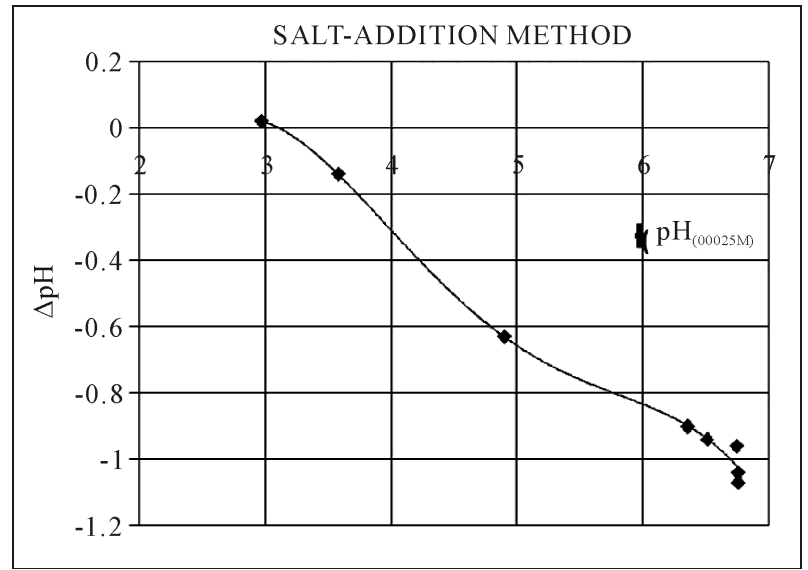

(b)

Figure 4. (a) Zeta potential measurements carried out on modified-brick grains (with $\leq 0.63 \mu \mathrm{m}$ sizes) in water at various $\mathrm{pH}$ values ranging from 3 to 9 . (b) Salt-addition method applied to modified-brick grains (with $0.7-1.0 \mathrm{~mm}$ sizes) at $\mathrm{pH}$ varying from 3 to $\sim 7$. IEP values for: activated brick (with $6 \mathrm{M}$ $\mathrm{HCl}$ for $3 \mathrm{~h}$ at $90^{\circ} \mathrm{C}$ ), $A B$; raw brick, $R B$; pure ferrihydrite, $F$.

\subsection{Implication of Electrostatic Forces at the Brick-Water Interface}

In a previous work [12], we found that kinetic data relative to the adsorption of divalent cations $\left(\mathrm{Cd}^{2+}, \mathrm{Cu}^{2+}\right.$, $\mathrm{Pb}^{2+}, \mathrm{Sr}^{2+}$ and $\mathrm{Zn}^{2+}$ ) onto this modified brick fitted better the pseudo-second-order model proposed by Ho and McKay [23] [24]. Figure 5(a) shows how these rate constants, $k_{2}$, are dependent upon the acidity constant of these metals, $\mathrm{pK}_{\mathrm{A}}$ (according to the reaction: $\mathrm{Me}^{2+}+\mathrm{H}_{2} \mathrm{O} \leftrightarrow \mathrm{Me}(\mathrm{OH})^{+}+\mathrm{H}^{+}$[25]-[27]), or vary with the starting $\mathrm{pH}$ of the reaction medium measured in a "water + brick" suspension at $298^{\circ} \mathrm{K}$ (Figure $5(\mathrm{~b})$ ). As a whole, an increase in the starting $\mathrm{pH}$ or $\mathrm{pK}_{\mathrm{A}}$ results in increasing metal adsorption rate, thus revealing the process to be intimately dependent upon $\mathrm{H}^{+}$and $\mathrm{OH}^{-}$ions. Indeed, hydrogen and hydroxyl ions have long been considered to be potential determining in the adsorption of hydrolysable metal ions at the oxide-water interface [10]. Since the charge of the brick surface seems to be affected by $\mathrm{pH}$, the removal by electrostatic attraction is expected to occur in our experiments between absorbent and cation having opposite charges. In this context, the interfacial chemical reactions (protonation/deprotonation of hydroxyl groups, $\equiv \mathrm{SOH}$, in ferrihydrite, and partially in silanol and/or aluminol from brick metakaolinite) should contribute to develop an electrostatic potential that has to be assessed. When brick is in an equilibrium state with water, the following acid-base equilibria are assumed to intervene at the water-brick interface: 


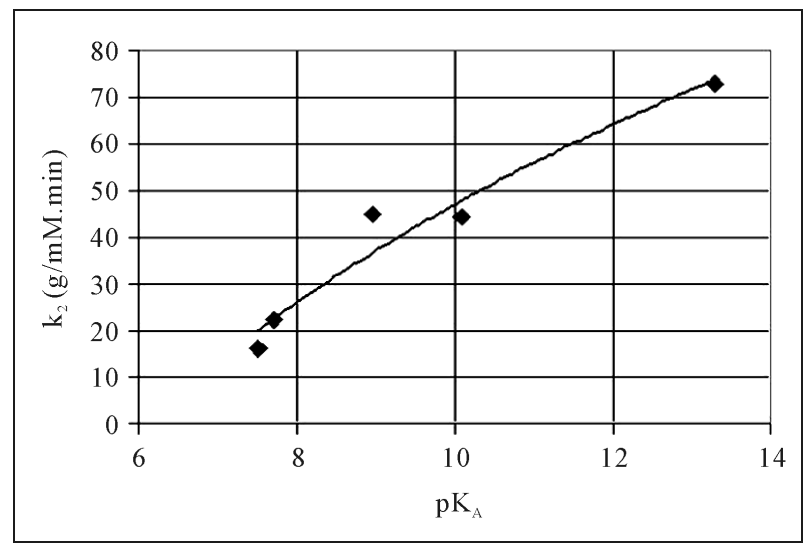

(a)

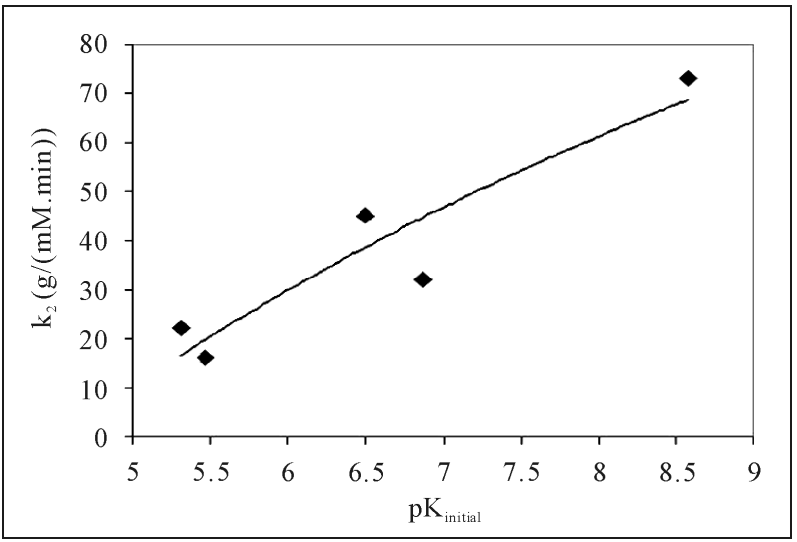

(b)

Figure 5. (a) Pseudo-second order kinetic rate $\left(k_{2}\right)$ for the metal-adsorption process plotted against the acidity constant of the metal in water $\left(\mathrm{pK}_{\mathrm{A}}\right)$ as: $\mathrm{Me}^{2+}+\mathrm{H}_{2} \mathrm{O} \leftrightarrow \mathrm{Me}(\mathrm{OH})^{+}+$ $\mathrm{H}^{+}$. (b) Rate constant $\left(\mathrm{k}_{2}\right)$ plotted against initial $\mathrm{pH}\left(\mathrm{pH}_{\mathrm{i}}\right)$.

$$
\begin{aligned}
& \equiv \mathrm{SOH}_{\text {(brick) }}+\mathrm{H}_{2} \mathrm{O} \equiv \mathrm{SO}_{\text {(brick) }}^{-}+\mathrm{H}_{3} \mathrm{O}^{+} \\
& \equiv \mathrm{SOH}_{(\text {brick) }}+\mathrm{H}_{3} \mathrm{O}^{+} \equiv \mathrm{SOH}_{2 \text { (brick) }}^{+}+\mathrm{H}_{2} \mathrm{O}
\end{aligned}
$$

Formation and dissociation of $\mathrm{H}_{3} \mathrm{O}^{+}$ions from the surface hydroxyls could therefore account for the surface charge, $\sigma$, on the brick which is given by:

$$
\sigma=\left[\equiv \mathrm{SOH}_{2}^{+}\right]-\left[\equiv \mathrm{SO}^{-}\right]
$$

And the site density can be written as:

$$
d_{\text {site }}=\left[\equiv \mathrm{SOH}_{2}^{+}\right]+\left[\equiv \mathrm{SO}^{-}\right]+[\equiv \mathrm{SOH}]
$$

We used the electrostatic diffuse layer model (DLM) in order to express the surface charge $(\sigma)$ as a function of the potential at the brick surface ( $\psi_{0}$, also being known as the surface potential or total double layer potential). In this approach, the Gouy-Chapman relationship was employed as:

$$
\sigma=\left(8 \times 10^{3} \cdot \varepsilon_{0} \cdot \varepsilon_{r} \cdot R \cdot T \cdot I\right)^{1 / 2} \cdot \sinh \left[\frac{F \Psi_{0}}{(2 R T)}\right]
$$

where $\varepsilon_{0}$ is the permittivity of a vacuum $\left(\varepsilon_{0}=18.854 \times 10^{-12} \mathrm{C}^{2} \cdot \mathrm{J}^{-1} \cdot \mathrm{m}^{-1}\right)$; $\varepsilon_{r}$ is the relative permittivity of water $\left(\varepsilon_{r}=78.5\right.$ at $\left.298^{\circ} \mathrm{K}\right)$; " $I$ " is the ionic strength of the medium; $F$ Faraday constant; $R$ gas constant; $T$ absolute temperature. As a first approximation, the $\psi_{0}$ potential of an oxide surface varies with $\mathrm{pH}$ as [10]: 


$$
\Psi_{0}=\left[\frac{2.303 R T}{(\Delta z \cdot F)}\right] \cdot\left[\log \left(a_{\mathrm{H}^{+}}\right)-\log \left(a_{\mathrm{H}+\mathrm{PZC}}\right)\right]=\left[\frac{-2.303 R T}{(\Delta z \cdot F)}\right]\left(\mathrm{pH}-\mathrm{pH}_{\mathrm{PZC}}\right)
$$

where $a_{\mathrm{H}^{+}}$is the activity of potential-determining ions $\mathrm{H}^{+}$(for brick oxides) in the bulk of the solution in reference to that at the state of PZC, $a_{\mathrm{H}+\mathrm{PZC}} ; \Delta z$ corresponds to the change in the charge of surface groups (i.e., $\Delta z=$ +1 for protonation, and $\Delta z=-1$ for deprotonation); $\mathrm{R}, \mathrm{T}$ and $\mathrm{F}$ have their usual significance. In this context, we plotted the pseudo-second order kinetic rate, $k_{2}$, relative to metal-adsorption kinetics against the surface potential $\left(\psi_{0}\right)$ which was measured at the beginning of the kinetic process (Figure 6). It can be seen in this figure that the higher the $\psi_{0}$ potential, the speedier the cationic species can adsorb on the negatively charged mineral surface. This finding demonstrates clearly that electrostatic attractions are implicated in this process and the rate constant is strongly related to the extent of the surface potential, $\psi_{0}$.

Consequently, attractive Coulombic force should presumably be a relevant contribution in the overall free energy change $\left(\Delta G_{\text {ads }}\right)$ for this adsorption process. To support this hypothesis and to assess the importance of this force on the kinetic reaction, some theoretical energetic aspects of the studied system were addressed in Section 3.5 .

\subsection{Energetic Aspects of the Adsorption Process}

The surface complexation model proposed by James and Healy [10] was used in the past in order to evaluate the adsorption characteristics of ions on oxide surfaces [28]-[30]. In the present work, we applied this model to determine the change of the total free energy of divalent-cation adsorption onto modified brick in water from the following equation:

$$
\Delta G_{\text {ads }}=\Delta G_{\text {coul }}+\Delta G_{\text {solv }}+\Delta G_{\text {chem }}
$$

where $\Delta G_{\text {Coul }}, \Delta G_{\text {solv }}$, and $\Delta G_{\text {chem }}$ represent the changes in free energy due to Coulombic (or electrostatic) effects, secondary solvation, and chemical interactions, respectively. Using the electrical double layer theory, the change of Coulombic energy can be determined from the equation [10]:

with

$$
\Delta G_{\text {coul }}=z_{i} F \Delta \Psi_{x}
$$

$$
\Delta \Psi_{x}=2 \frac{R T}{z F} \operatorname{Ln}\left[\frac{\left(\mathrm{e}^{\left(\frac{z F \Psi_{0}}{2 R T}\right)}+1\right)+\left(\mathrm{e}^{\left(\frac{z F \Psi_{0}}{2 R T}\right)}-1\right) \mathrm{e}^{-\kappa x}}{\left(\mathrm{e}^{\left(\frac{z F \Psi_{0}}{2 R T}\right)}+1\right)-\left(\mathrm{e}^{\left(\frac{z F \Psi_{0}}{2 R T}\right)}-1\right) \mathrm{e}^{-\kappa x}}\right]
$$

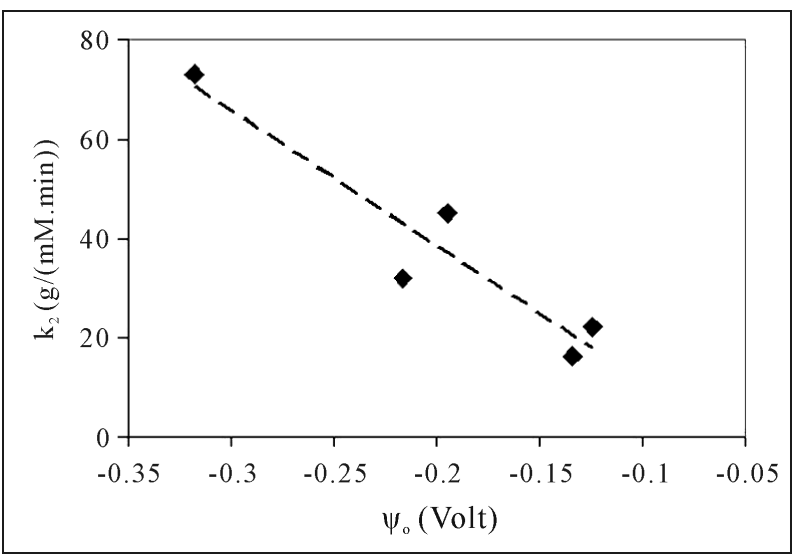

Figure 6. Pseudo-second order kinetic rate $\left(\mathrm{k}_{2}\right)$ for the metaladsorption process plotted against the surface potential of the modified brick $\left(\psi_{0}\right)$ measured at the beginning of the reaction. 
$\Psi_{0}=\frac{2.303 R T}{z F}\left(\mathrm{pH}_{\mathrm{PZC}}-\mathrm{pH}\right)$, where $\Psi_{0}$ is the surface potential as defined above;

$x=\left(R_{\text {cation }}+2 R_{\text {water }}\right)$, where $x$ is the hydrated ionic radius of the cation, and $R_{\text {cation }}$ and $R_{\text {water }}$ are the radii of cation and water, respectively;

$z_{i}=$ charge on the adsorbing ion

$z=1$ for $1: 1$ (background electrolyte).

$\kappa$ represents the Debye-Huckel reciprocal double-layer length which depends up the ionic strength, $I$, of the medium as:

$$
\kappa=3.31 \times 10^{9} \sqrt{I}\left(\mathrm{~m}^{-1}\right) \text { with } I=\frac{1}{2} \sum z_{i}^{2} C_{i}
$$

where $z_{i}$ is the charge of the metal cation and $C_{i}$ is the ions concentration in water. $\kappa$ was calculated for our system. We found: $\kappa \cong 1.94 \times 10^{9} \mathrm{~m}^{-1}$ with $I \cong 3.44 \times 10^{-1} \mathrm{~mol} / \mathrm{m}^{3}$.

As for the change of free energy due to effects associated with secondary solvation, its contribution is given by [10]:

$$
\begin{aligned}
\Delta G_{\text {solv }}= & \left(\frac{z_{i}^{2} e^{2} N}{16 \pi \varepsilon_{0}}\right)\left(\frac{1}{R_{\text {cation }}+2 R_{\text {water }}}-\frac{R_{\text {cation }}}{2\left(R_{\text {cation }}+2 R_{\text {water }}\right)^{2}}\right)\left(\frac{1}{\varepsilon_{\text {int }}}-\frac{1}{\varepsilon_{\text {bulk }}}\right) \\
& +\left(\frac{z_{i}^{2} e^{2} N}{32 \pi \varepsilon_{0}}\right)\left(\frac{1}{R_{\text {cation }}+2 R_{\text {water }}}\right)\left(\frac{1}{\varepsilon_{\text {solid }}}-\frac{1}{\varepsilon_{\text {int }}}\right)
\end{aligned}
$$

where $\varepsilon_{\text {int }}=\left(\frac{\varepsilon_{\text {bulk }}-6}{1+1.2 \times 10^{-17}(\mathrm{~d} \Psi / \mathrm{d} x)_{x}^{2}}\right)+6$ and $\frac{\mathrm{d} \Psi}{\mathrm{d} x}=-2 \kappa \frac{R T}{\mathrm{zF}} \sinh \left(\frac{\mathrm{z} F \Delta \Psi_{x}}{2 R T}\right)$

The radius of water was assumed to be that of oxygen $\left(1.38 \times 10^{-10} \mathrm{~m}\right)[10]$; $\varepsilon_{\text {bulk }}$ and $\varepsilon_{\text {solid }}$ are the dielectric constants for aqueous solution $\left(\varepsilon_{\text {bulk }} \approx 78.5\right)$ and $\mathrm{FeOOH}$ adsorbed onto brick $\left(\varepsilon_{\text {solid }} \approx 11.70\right.$ [31]), respectively; $R$ is the universal gas constant $(8.314 \mathrm{~J} /(\mathrm{mol} \cdot \mathrm{K}))$; The $R_{\text {cation }}$ values used in this work were those reported by Marcus [32]. The $\Delta G_{\text {Coul }}$ and $\Delta G_{\text {solv }}$ values were reported in Table 2. As a whole, the experimental $\Delta G^{0}$ value was found to be close enough to the sum: $\Delta G_{\text {Coul }}+\Delta G_{\text {solv }}$, indicating that the contribution of the specific chemical interaction, $\Delta G_{\text {chem }}$, was weak during the time interval of kinetic experiments ( $<1$ hour). It can be concluded that both the attractive Coulombic force and the repulsive secondary solvation force contribute mostly to the overall free energy change observed during metal-adsorption kinetics.

\subsection{Effect of an Inert Electrolyte $\left(\mathrm{NaNO}_{3}\right)$ on the Adsorption Process}

Under dynamic conditions by using a fixed-bed column (as stated in the experimental section), the effectiveness of this modified brick in the removal of a divalent metal like $\mathrm{Cd}^{++}$was examined. The $\mathrm{Cd}^{++}$content in the column influent was fixed at $1.79 \times 10^{-4} \mathrm{~mol} / \mathrm{L}$ which corresponds to $20.1 \mathrm{mg}$ of cadmium per liter. Experimental data are presented graphically on Figure 7(a). To access the adsorption performance of this material, the breakthrough time $\left(t_{b}\right)$ and the exhaustive time $\left(t_{e}\right)$ were determined under given operational conditions: they were

Table 2. Gibbs-free energies relative to the attractive Coulombic force $\left(\Delta G_{\text {Coul. }}\right)$ and the repulsive secondary solvation force $\left(\Delta G_{\text {solv. }}\right.$ ) calculated by using the surface complexation model proposed by James and Healy [10]. The sum " $\Delta G_{\text {Coul. }}+\Delta G_{\text {solv." }}$ was compared to the Gibbs-free energy, $\Delta G^{0}$, for the adsorption kinetics process.

\begin{tabular}{ccccc}
\hline Metals & $\Delta G_{\text {Coul. }}(\mathrm{kJ} / \mathrm{mol})$. & $\Delta G_{\text {solv. }}(\mathrm{kJ} / \mathrm{mol})$. & $\Delta G_{\text {Coul. }}+\Delta G_{\text {solv. }}(\mathrm{kJ} / \mathrm{mol})$. & $\Delta G^{0} 298 \mathrm{~K}(\mathrm{~kJ} / \mathrm{mol})$ \\
\hline $\mathrm{Cd}^{2+}$ & -10.277 & +5.4195 & -4.857 & -5.940 \\
$\mathrm{Cu}^{2+}$ & -8.473 & +5.7328 & -2.740 & -1.342 \\
$\mathrm{~Pb}^{2+}$ & -8.204 & +5.070 & -3.135 & -2.889 \\
$\mathrm{Sr}^{2+}$ & -10.103 & +5.170 & -4.938 & -6.574 \\
$\mathrm{Zn}^{2+}$ & -10.760 & +5.764 & -4.998 & -1.422 \\
\hline
\end{tabular}


defined as the elapsed time values when the effluent $\mathrm{Cd}^{2+}$ concentration $\left(C_{t}\right)$ attained $5 \%\left(t_{b}\right)$ and $95 \%\left(t_{e}\right)$ of the influent $\mathrm{Cd}^{2+}$ concentration $\left(C_{0}\right)$. It can be seen in Figure 7(a) that the effluent volume at breakthrough time is $\sim 500 \mathrm{~mL}$ and at exhaustive time $\sim 1500 \mathrm{~mL}$. Also, another column experiment was carried out by passing through the brick column a Cd(II) solution at the same concentration as that before, however, by adding further an inert electrolyte: $\mathrm{NaNO}_{3}\left(10^{-1} \mathrm{M}\right)$ in the aim to study the influence of an increase of the ionic strength on the adsorption (Figure 7(a)). The resulting breakthrough curve (Figure 7(a)) shows clearly an inhibition of the adsorption process as a result of the addition of $\mathrm{NaNO}_{3}$ salt: indeed both the breakthrough time and exhaustive time decreased significantly. Such a reaction inhibition could be attributed to a charge reversal at the brick surface in highly concentrated electrolyte. It should be noted that this phenomenon had previously been observed on other oxides like: aluminum hydroxide/oxide [33] [34], anatase [35], and hematite particles [36]. In our case, the electrokinetic effect at high ionic strength could be due to the occupation of most surface sites of the brick by a specifically adsorbed ion that would be the $\mathrm{Na}^{+}$species in excess in the influent. It was also observed that the addition of an inert electrolyte led to an increase of the medium acidity or a decrease of $\mathrm{pH}$ (see Figure 7(b)). Consequently, the surface potential, $\Psi_{0}$, diminishes as well with a decrease of $\mathrm{pH}$ according to Equation (9).

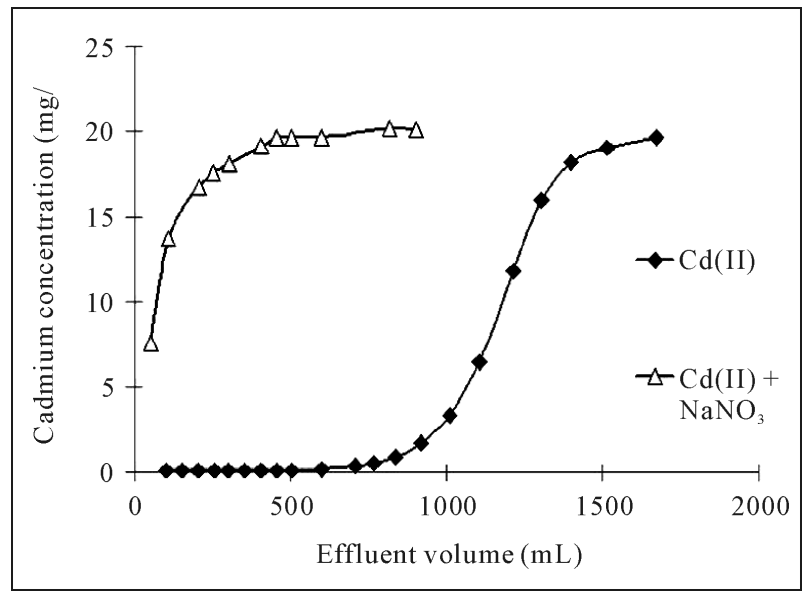

(a)

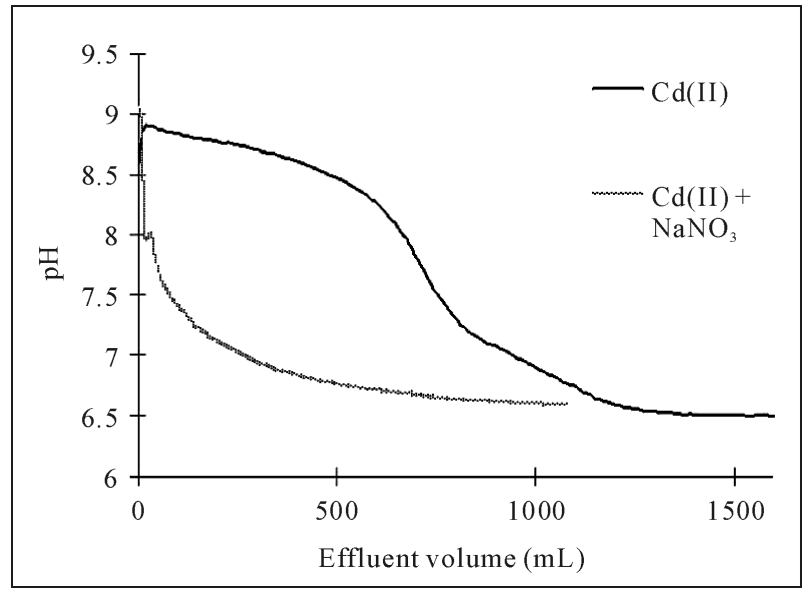

(b)

Figure 7. (a) Specific breakthrough curve of cadmium(II) obtained by using a column of modified brick grains (with $0.7-1.0 \mu \mathrm{m}$ sizes) for a flow rate of $10 \mathrm{~mL} / \mathrm{min}$ and a bed height of $8.5 \mathrm{~cm}$ (with an inside column diameter of $12.5 \mathrm{~mm}$ ) and an influent concentration of $1.79 \times 10^{-4}$ mole per liter: without ( $\bullet$; and with an inert electrolyte, $\mathrm{NaNO}_{3}(\Delta)$. (b) Variation of the effluent $\mathrm{pH}$ during these two column experiments. 
Therefore, any electrostatic forces at the water-brick interface tend to be canceled out and cation migration as well, in agreement with results obtained experimentally with fixed-bed column.

\section{Conclusion}

This work focuses on the $\mathrm{pH}$-dependence of surface characteristics of ferrihydrite-coated brick on divalent-cation adsorption and its implication on the kinetics process. Using SEM/EDS, it was found that ferrihydrite was preferentially attached to alumino-silicates and $\mathrm{Na}$ atoms are strongly involved in iron-rich aggregates (noted $\equiv \mathrm{SO}^{-} \mathrm{Na}^{+}$). Thermodynamic parameters were in magnitude with those reported in the literature when a physisorption mechanism occurred in a solid-water system. Electro-kinetic studies indicated that the $\mathrm{pH}_{\mathrm{PZC}}$ value is close to $\mathrm{pH}_{\mathrm{IEP}}(\sim 3.2)$. In most of our applications in the field, modified-brick surfaces were negatively charged in natural waters (with $\mathrm{pH}>4$ ) and thereby possessed a potential capacity for the attraction of cationic species. Moreover, adsorption kinetics was strongly dependent upon $\mathrm{Na}^{+}, \mathrm{H}^{+}$and $\mathrm{OH}^{-}$ions due to their exchanges at the brick-water interface. The possibility of ionic-exchanges reactions contributed to generate surface charges on the brick and therefore a surface potential, $\left(\psi_{0}\right)$, with the strong implication of $\mathrm{H}^{+}$and $\mathrm{OH}^{-}$ions which behaved as potential-determining ions on the brick surface. The magnitude of the $\psi_{0}$ potential was found to be intimately related to the extent of the pseudo second order kinetic rate, $\mathrm{k}_{2}$. To explain this, Gibbs free energies for divalent-cations adsorption were calculated by using the complexation model proposed by James and Healy [10], and theoretical free-energy changes revealed the importance of both the attractive Coulombic force and the repulsive secondary solvation force in our system. Column experiments permitted us to show that this adsorption process was inhibited after addition in the influent of an inert electrolyte like $\mathrm{NaNO}_{3}$. Indeed, this inhibition decreased the surface potential, $\psi_{0}$, of the brick, and led to the cancellation of most of the electrostatic forcesinitially involving at the water-brick interface-and, consequently, cation migration.

\section{Acknowledgements}

This work is partly funded by the "Artois-Picardie Water Agency" and the "General Council of the Northern region of France". The study is part of Oscar Allahdin's thesis which is currently underway, and results from the cooperation between the University of Lille1 (France) and the University of Bangui (Central African Republic). This collaboration and the Grant-in Aid to Mr. O. Allahdin for his scientific research are financially supported by the Embassy of France to Bangui.

\section{References}

[1] Babel, S. and Kurniawan, T.A. (2003) Low-Cost Adsorbents for Heavy Metals Uptake from Contaminated Water: A Review. Journal of Hazardous Materials, 97, 219-243. http://dx.doi.org/10.1016/S0304-3894(02)00263-7

[2] Bathnagar, A. and Sillanpää, M. (2010) Utilization of Agro-Industrial and Municipal Waste Materials as Potential Adsorbents for Water Treatment-A Review. Chemical Engineering Journal, 157, 277-296. http://dx.doi.org/10.1016/j.cej.2010.01.007

[3] Sud, D., Mahajan, G. and Kaur, M.P. (2008) Agricultural Waste Material as Potential Adsorbent for Sequestering Heavy Metal Ions from Aqueous Solutions-A Review. Bioresource Technology, 99, 6017-6027. http://dx.doi.org/10.1016/j.biortech.2007.11.064

[4] Kurniawan, T.A., Chan, G.Y.S., Lo, W.H. and Babel, S. (2006) Comparison of Low-Cost Adsorbents for Treating Wastewater Laden with Heavy Metals. Sci. total Environ, 366, 409-426. http://dx.doi.org/10.1016/j.scitotenv.2005.10.001

[5] Dehou, S.D., Wartel, M., Recourt, P., Revel, B., Mabingui, J., Montiel, A. and Boughriet, A. (2012) Physicochemical, Crystalline and Morphological Characteristics of Bricks Used for Ground Waters Purification in Bangui Region (Central African Republic). Applied Clay Science, 59-60, 69-75. http://dx.doi.org/10.1016/j.clay.2012.02.009

[6] Dehou, S.C., Wartel, M., Recourt, P., Revel, B. and Boughriet, A. (2012) Acid Treatment of Crushed Brick (from Central African Republic) and Its Ability (after FeOOH Coating) to Adsorb Ferrous Ions from Aqueous Solutions. The open Materials Science Journal, 6, 50-59.

[7] Dehou, S.C., Mabingui, J., Lesven, L., Wartel, M. and Boughriet, A. (2012) Improvement of Fe(II)-Adsorption Capacity of FeOOH-Coated Brick in Solutions, and Kinetics Aspects. Journal of Water Resource and Protection, 4, 464-473. http://dx.doi.org/10.4236/jwarp.2012.47054

[8] Allahdin, O., Dehou, S.C., Wartel, M., Recourt, P., Trentesaux, M., Mabingui, J. and Boughriet, A. (2013) Perfor- 
mance of FeOOH-Brick Based Composite for Fe(II) Removal from Water in Fixed Bed Column and Mechanistic Aspects. Chemical Engineering Research and Design, 91, 2732-3742. http://dx.doi.org/10.1016/j.cherd.2013.04.006

[9] Allahdin, O., Wartel, M., Recourt, P., Revel, B., Ouddane, B., Billon, G., Mabingui, J. and Boughriet A. (2014) Adsorption Capacity of Iron Oxihydroxide-Coated Brick for Cationic Metals and Nature of Ion-Surface Interactions. Applied Clay Science, 90, 141-149. http://dx.doi.org/10.1016/j.clay.2014.01.008

[10] James, R.O. and Healy, T.W. (1972) Adsorption of Hydrolysable Metal Ions at the Oxide-Water Interface. Journal of Colloid and Interface Science, 40, 65-81. http://dx.doi.org/10.1016/0021-9797(72)90174-9

[11] Uehara, G. and Gillman, G.P. (1981) The Mineralogy, Chemistry and Physics of Tropical Soils with Variable Charge Clays. West View Press, Boulder, 145.

[12] Allahdin, O., Wartel, M., Mabingui, J. and Boughriet, A. (2014) Kinetics of Divalent Metals $\left(\mathrm{Cd}^{2+}, \mathrm{Cu}^{2+}, \mathrm{Pb}^{2+}, \mathrm{Zn}^{2+}\right)$ Adsorption onto a Modified Brick: Influence of Surface Charge. American Chemical Science Journal, 4, 687-705.

[13] Özcan, A., Öncü, E.M. and Özcan, A.S. (2006) Adsorption of Acid Blue 193 from Aqueous Solutions onto DEDMA-Sepiolite. Journal of Hazardous Materials, 129, 244-252.

[14] Anirudhan, T.S. and Radhakrishnan, P.G. (2008) Thermodynamic and Kinetics of Adsorption of Cu(II) from Aqueous Solutions onto a New Cation Exchanges Derived from Tamarind Fruit Shell. Journal of Chemical Thermodynamics, 40, 702-709. http://dx.doi.org/10.1016/j.jct.2007.10.005

[15] Liang, S., Guo, X., Feng, N. and Tian, Q.H. (2010) Isotherms, Kinetics and Thermodynamics Studies of Adsorption of $\mathrm{Cu}^{2+}$ from Aqueous Solutions by $\mathrm{Mg}^{2+} / \mathrm{K}^{+}$Type Orange Peel Adsorbents. Journal of Hazardous Materials, 174, 756-762. http://dx.doi.org/10.1016/j.jhazmat.2009.09.116

[16] Mohapatra, M. and Anand, S. (2007) Studies on Sorption Cd(II) on Tata Chromite Mine Overburden. Journal of Hazardous Materials, 148, 553-559.

[17] Mohapatra, M., Khatun, S. and Anand, S. (2009) Kinetics and Thermodynamics of Lead (II) Adsorption on Lateritic Nickel Ores of Indian Origin. Chemical Engineering Journal, 155, 184-190. http://dx.doi.org/10.1016/j.cej.2009.07.035

[18] Jaycock, M.J. and Parfitt, G.D. (1981) Chemistry of Interfaces. Ellis Horwood Ltd., Chichester.

[19] Kuo, C.Y., Wu, C.H. and Wu, J.Y. (2008) Adsorption of Direct Dyes from Aqueous Solutions by Carbon Nanotubes Determination of Equilibrium, Kinetic and Thermodynamics Parameters. Journal of Colloid and Interface Science, 327, 308-315. http://dx.doi.org/10.1016/j.jcis.2008.08.038

[20] Chen, S., Yue, Q., Gao, B.Y. and Xu, X. (2010) Equilibrium and Kinetic Adsorption Study of the Adsorptive Removal of Using Modified Wheat Residue. Journal of Colloid and Interface Science, 349, 256-264. http://dx.doi.org/10.1016/j.jcis.2010.05.057

[21] Kosmulski, M. (2009) Compilation of PZC and IEP of Sparingly Soluble Metal Oxides and Hydroxides from Literature. Advances in Colloid and Interface Science, 152, 14-25. http://dx.doi.org/10.1016/j.cis.2009.08.003

[22] Ji, Y. (2014) Ions Removal by Iron Nanoparticles: A Study on Solid-Water Interface with Zeta Potential. Colloids and Surfaces A: Physicochemical and Engineering Aspects, 444, 1-8. http://dx.doi.org/10.1016/j.colsurfa.2013.12.031

[23] Ho, Y.S. and McKay, G. (1998) The Kinetics of Sorption of Basic Dyes from Aqueous Solution by Sphagnum Moss Peat. Canadian Journal of Chemical Engineering, 76, 822-827. http://dx.doi.org/10.1002/cjce.5450760419

[24] Ho, Y.S. (2006) Review of Second-Order Models for Adsorption Systems. Journal of Hazardous Materials, 136, 281-689. http://dx.doi.org/10.1016/j.jhazmat.2005.12.043

[25] Gu, X. and Evans, L.J. (2008) Surface Complexation Modelling of Cd(II), Cu(II), Ni(II), Pb(II) and Zn(II) Adsorption onto Kaolinite. Geochimica et Cosmochimica Acta, 72, 267-276. http://dx.doi.org/10.1016/j.gca.2007.09.032

[26] Charlot, G. (1963) Qualitative Analyses and Reactions in Solution. Masson \& Cie, Paris, 442.

[27] Martell, A.E. and Smith, R.M. (2004) NIST Standard Reference Database 46, Version 7.0. NIST, Gaithersburg.

[28] Agashe, K.B. and Regalbuto, J.R. (1997) A Revised Physical Theory for Adsorption of Metal Complexes at Oxide Surfaces. Journal of Colloid and Interface Science, 185, 174-189. http://dx.doi.org/10.1006/jcis.1996.4493

[29] Hao, X., Spieker, W.A. and Regalbuto, J.R. (2003) A Further Simplification of the Revised Physical Adsorption (RPA) Model. Journal of Colloid and Interface Science, 267, 259-264. http://dx.doi.org/10.1016/S0021-9797(03)00644-1

[30] Yan, L., Masliyah, J.H. and Xu, Z.H. (2013) Interaction of Divalent Cations with Basal Planes and Edge Surfaces of Phyllosilicate Minerals: Muscovite and Talc. Journal of Colloid and Interface Science, 404, 183-191. http://dx.doi.org/10.1016/j.jcis.2013.04.023

[31] Sahai, N. (2000) Estimating Adsorption Enthalpies and Affinity Sequences of Monovalent Electrolyte Ions on Oxide Surfaces in Aqueous Solution. Geochimica et Cosmochimica Acta, 64, 3629-3641. http://dx.doi.org/10.1016/S0016-7037(00)00431-2 
[32] Marcus, Y. (1991) Thermodynamics of Solvation of Ions. Part 5-Gibbs Free Energy of Hydration at 298.15 K. Journal of the Chemical Society, Faraday Transactions, 87, 2995-2999. http://dx.doi.org/10.1039/ft9918702995

[33] Rowlands, W.N., O’Brien, R.W., Hunter, R.J. and Patrick, V.J. (1997) Surface Properties of Aluminum Hydroxide at High Salt Concentration. Journal of Colloid and Interface Science, 188, 325-335. http://dx.doi.org/10.1006/jcis.1997.4762

[34] Johnson, S.B., Scales, P.J. and Healy, T.W. (1999) The Binding of Monovalent Electrolyte Ions on $\alpha$-Alumina. I. Electroacoustic Studies at High Electyrolyte Concentrations. Langmuir, 15, 2836-2843. http://dx.doi.org/10.1021/la980875f

[35] Kosmulski, M., Dukhin, A.S., Priester, T. and Rosenholm, J.B. (2003) Multilaboratory Study of the Shifts in the IEP of Anatase at High Ionic Strengths. Journal of Colloid and Interface Science, 263, 152-155. http://dx.doi.org/10.1016/S0021-9797(03)00328-X

[36] Siebentritt, M., Volovitch, P., Ogle, K. and Lefèvre, G. (2014) Surface Potential of Hematite Particles in High Concentration Electrolytes: Electroacoustic Measurements and Suspension Stability. Colloids and Surfaces A: Physicochemical and Engineering Aspects, 443, 338-344. http://dx.doi.org/10.1016/j.colsurfa.2013.11.039 
Scientific Research Publishing (SCIRP) is one of the largest Open Access journal publishers. It is currently publishing more than 200 open access, online, peer-reviewed journals covering a wide range of academic disciplines. SCIRP serves the worldwide academic communities and contributes to the progress and application of science with its publication.

Other selected journals from SCIRP are listed as below. Submit your manuscript to us via either submit@scirp.org or Online Submission Portal.
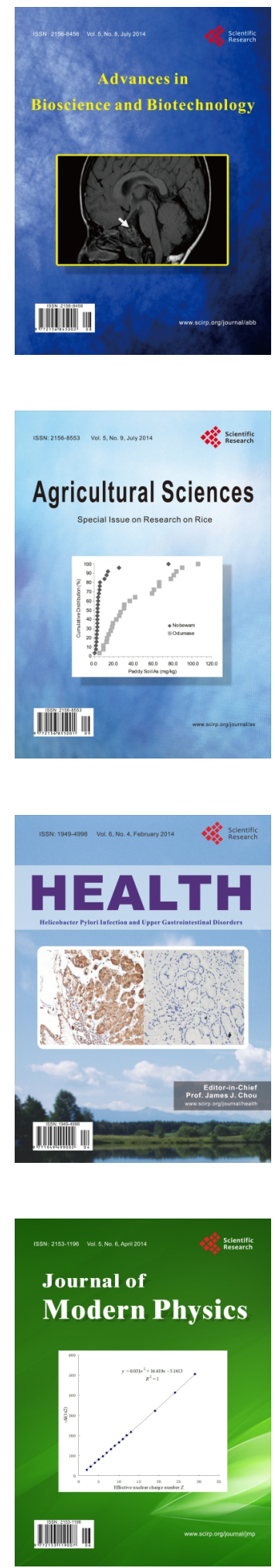
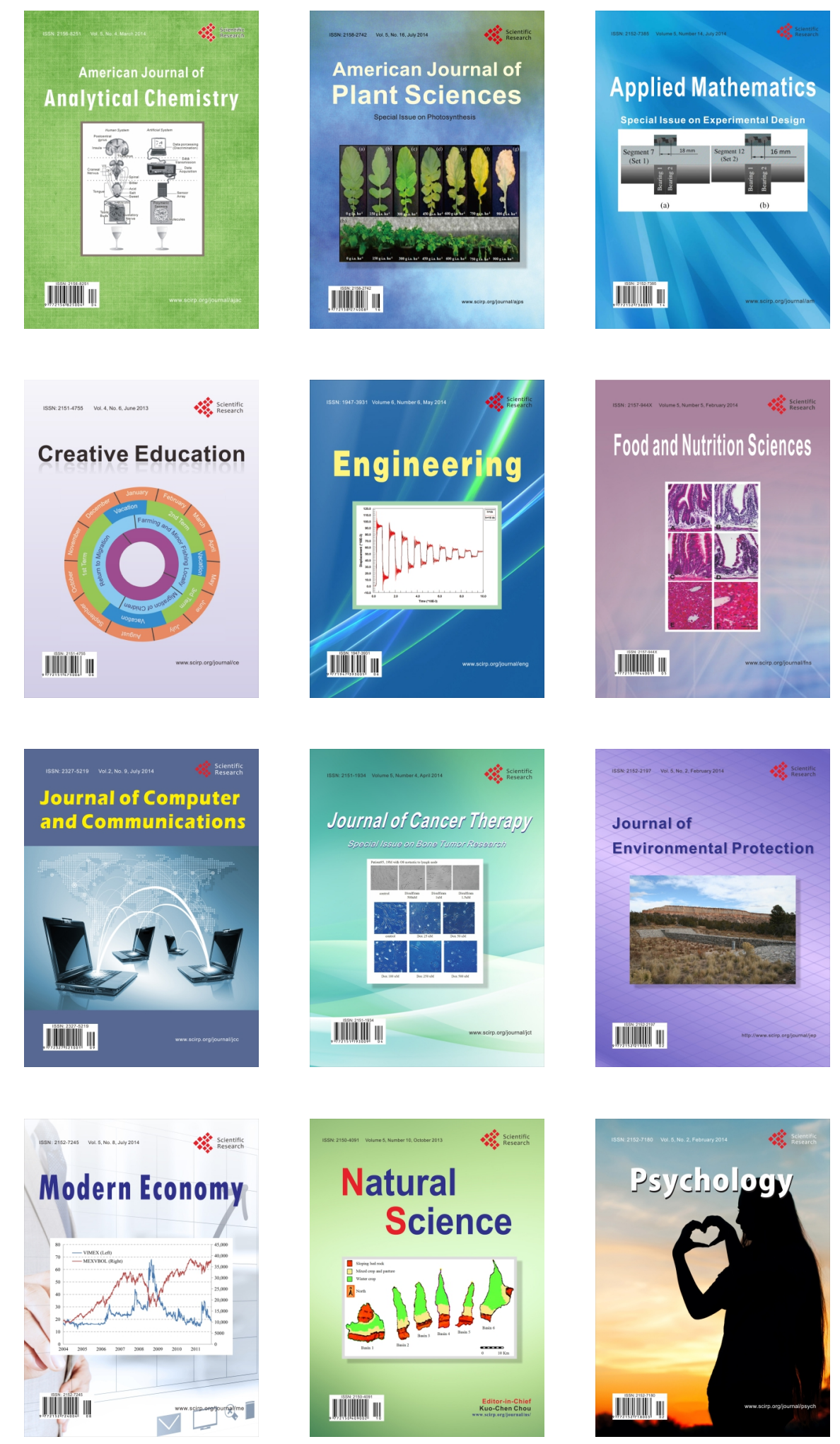